\title{
Rethinking the Use of Antitrust Law in Combat Sports
}

\author{
Jason J. Cruz
}

\section{Introduction}

This article will examine the application of antitrust laws in combat sports. Specifically, it will look at three recent cases involving lawsuits brought under the Sherman Act Section 1 and 2. ${ }^{1}$ First, this article will examine the January 2017 dismissal by a Los Angeles federal court of a lawsuit filed by Golden Boy Promotions ("Golden Boy") against Al Haymon and his business entities, which started Premier Boxing Champions ("PBC"). ${ }^{2}$ It will also examine Top Rank Boxing's ("Top Rank") similar lawsuit against Haymon, which was settled the previous fall. Finally, it will evaluate the ongoing lawsuit between several former fighters and the Ultimate Fighting Championships ("UFC").

While each lawsuit has its own set of facts, the conditions and marketplace for combat sports is unique and the application of antitrust law has been used sparingly by boxers and promoters. These three cases filed in the last three years reflect the changing market for boxing and MMA.

The paper will look at the results of the Top Rank and Golden Boy lawsuits and determine whether those cases shed any light on the outcome of the UFC case. It will also explore whether there are alternatives to regulating combat sports outside of the use of the antitrust laws. One legal commentator has opined that a federal commission would aid the monopolistic structure of a sports league. But, does that apply to individual sports like MMA or boxing? This paper will explore this issue as well as determine whether organizing fighters would address the issues complained of in the lawsuits.

\footnotetext{
* Jason J. Cruz, JD, owns and operates Cruz Law, PLLC in Seattle, Washington, and is the editor-in-chief of MMAPayout.com; email: jason@cruzlawpllc.com

${ }^{1}$ Although the lawsuits discussed include more causes of action, the focus of this article will be on 15 U.S.C. $\$ 1$ and $\S 2$, the Sherman Antitrust Act 1 and 2.

${ }^{2}$ On February 27, 2017, Golden Boy filed a notice of appeal of the federal court decision dismissing its lawsuit. See Plaintiffs' Notice of Appeal and Representation Statement, Case No. 2:15-cv-03378 JFW (MRWx), February 27, 2017, ECF No. 343. The case has since been settled. See Stipulated Dismissal for Dismissal of Appeal, Appeal No. 17-55259, 9th Cir. Ct. of Appeals, October 25, 2017.
}

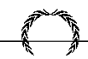




\section{Background}

\section{The Traditional Structures of Boxing and MMA}

Professional boxing and MMA are unlike traditional team sports like the National Football League, National Basketball Association, the National Hockey League, or Major League Baseball. Boxing and MMA are governed by each particular state regulating events to ensure fighter safety. In professional bouts, boxers and MMA fighters must obtain licenses to fight in the state. In most instances, the state athletic commission and/or licensing authority shall issue specific rules for boxing and MMA as well as issue penalties if it is determined that there is a violation.

In boxing, there are several sanctioning organizations that recognize professional boxing world champions. The major sanctioning bodies include the International Boxing Federation, World Boxing Association, World Boxing Council, and the World Boxing Organization. In the business of boxing, the sanctioning bodies play a small part in comparison to promoters within the sport. Promoters work with fighters to put on fights and events. Promoters work with sanctioning bodies to coordinate events. World titles are secondary to fight purses and boxers have been known to relinquish titles in order to work with other organizations.

Boxing relies on state commissions to determine the nature of drug testing. There are few commissions that test for performance enhancing substances. Certain boxing organizations work through a third-party vendor to conduct drug testing. Drug testing becomes a negotiable contracting term with regard to when and how competitors fight for an individual bout. Uniformity is an issue in boxing due to the cost of testing as well as the differences between states.

Unlike any other MMA organization, the UFC has its own anti-doping policy, which is administered by a third party, the United States Anti-Doping Association ("USADA"). The Anti-Doping Policy is modeled on the World Anti-Doping Code. $^{3}$ Each UFC contracted fighter can be randomly tested by USADA. There is an appeal board comprised of an independent third-party entity in the case that a fighter is punished for a purported violation of the policy and then issued a suspension and/or fine. Other organizations devise their own anti-doping drug testing policies and/or follow the lead of the athletic commission or licensing agency with respect to drug testing.

The UFC is the main promotion in the sport. In July 2016, WME-IMG purchased the company for $\$ 4.2$ billion. ${ }^{4}$ The company has contracts with more than 500 fighters competing in divisions based on weight limits (i.e., lightweight, welterweight, middleweight, heavyweight, etc.). The fighters are designated as independent contractors and not employees of the promotion. Bellator

\footnotetext{
${ }^{3}$ USADA UFC Anti-Doping Program, April 2017, https://ufc.usada.org/wp-content/uploads/ UFC-Anti-Doping-Policy-effective-April-1-2017.pdf (last visited January 19, 2018).

${ }^{4}$ Darren Rovell \& Brett Okamoto, Dana White on \$4 Billion UFC Sale: 'Sport Is Going to the Next Level,' ESPN.com, July 11, 2017, http:/www.espn.com/mma/story/_id/16970360/ ufc-sold-unprecedented-4-billion-dana-white-confirms
} 
Championships is owned by cable conglomerate Viacom. Similar to the UFC, its fighters are independent contractors. Similar to boxing, state athletic commissions and licensing authorities handle issuing licenses, designating referees for fights, and other issues.

\section{Relevant Law Discussed}

\section{Sherman Act Antitrust $\$ 1$}

The Sherman Antitrust Act is one of the rules of law that govern antitrust law in the United States. It was enacted to protect trade and commerce against unlawful restraints and monopolies.

Section 1 of the Sherman Act addresses the nature of constraining interstate commerce. Violations of Section 1 of the Sherman Act are considered "per se" violations. A "per se" violation requires no further inquiry into the practice's actual effect on the market or the intentions of those individuals who engaged in the practice. According to 15 USC $\$ 1$, "Every contract, combination in the form of trust or otherwise, or conspiracy, in restraint of trade or commerce among the several States, or within foreign nations, is declared to be illegal."

In general, these types of restraint on trade agreed to between competitors, even indirectly, with pricing are per se illegal. A combination or conspiracy is established by proof of "a conscious commitment to a common scheme designed to achieve an unlawful objective." 5

Market power is the ability of a market participant to increase prices above levels that would be charged in a competitive market. ${ }^{6}$

\section{Sherman Antitrust Act $\$ 2$}

Section 2 of the Sherman Act makes it unlawful for any person to "monopolize, or attempt to monopolize, or conspire with any other person or persons, to monopolize any part of the trade or commerce among the several States, or with foreign nations." This section of the Sherman Act establishes three offenses commonly termed monopolization, attempted monopolization, and conspiracy to monopolize.

Monopolization requires (1) monopoly power and (2) the willful acquisition or maintenance of that power as distinguished from growth or development as a consequence of a superior product, business acumen, or historic accident.?

The three cases discussed herein address Section 2 of the Sherman Act as the plaintiffs accuse the alleged defendant of a monopoly or a scheme to monopolize a certain market. In the case of the lawsuits filed against PBC and Al Haymon, the market is claimed to be "Championship Caliber Boxers" and "Boxing." In the case of the UFC, the relevant output market is purportedly defined as "Elite

\footnotetext{
${ }^{5}$ Monsanto Co. v. Spray-Rite Service Corp., 465 U.S. 752, 764 (1984).

${ }^{6}$ NCAA v. Board of Regents of Univ. of Oklahoma, 468 U.S. 85, 109 (1984).

${ }^{7}$ The United States Department of Justice website, https://www.justice.gov/atr/competition-and-monopoly-single-firm-conduct-under-section-2-sherman-act-chapter-1 (last visited January 19, 2018).
} 
Professional MMA Fighter" bouts and the relevant input market is alleged by the plaintiffs as "Elite Professional MMA Fighter" services.

\section{Tying Arrangements}

The three combat sport lawsuits discussed herein accuse the defendant of an unlawful tying and/or tie-out arrangements. "A tying arrangement is a device used by a seller with market power in one product market to extend its market power to a distinct product market." ${ }^{8}$ In order to accomplish this, the competitor agrees "to sell one product (the tying product) but only on the condition that the buyer also purchase a different product (the tied product), or at least agrees that he will not purchase the tied product from any other supplier." "[T] characteristic of an invalid tying arrangement lies in the seller's exploitation of its control over the tying product to force the buyer into the purchase of a tied product that the buyer either did not want at all, or might have preferred to purchase elsewhere on different terms."10 "Tying arrangements are forbidden on the theory that, if the seller has market power over the tying product, the seller can leverage this market power through tying arrangements to exclude other seller of the tied product."11

Tying arrangements are considered a per se violation pursuant to Section 1 of the Sherman Act if the plaintiff establishes that: (1) the defendant tied together the sale of two distinct products or services; (2) the defendant possesses enough economic power in the tying product market to coerce its customers into purchasing the tied product; and (3) the tying arrangement affects a "not insubstantial volume of commerce" in the tied product market.

In the boxing lawsuits, Golden Boy and Top Rank believe that Haymon used his market power to facilitate tying arrangements that took the form of exclusive agreements with fighters. The plaintiffs also claimed that they were "tied out" of negotiating with fighters since they were not promoting the fighters. Additionally, they were "tied out" of networks airing its fights due to exclusive broadcast agreements. Finally, they claimed "venue blocking," in which rival promoters were precluded from reserving a preferred venue on a favorable date because Haymon had already reserved the venue. According to Golden Boy and Top Rank, this was done in an effort to ensure a rival promoter was unable to use the venue.

\section{Boxing's Fight for Dominance}

\section{The Origins of Golden Boy Boxing}

Golden Boy Boxing is a major player in the world of boxing as it is one of the biggest boxing promoters in the industry. Named after the nickname of former

\footnotetext{
${ }^{8}$ See Cascade Health Solutions v. PeaceHealth, 515 F.3d 883, 912 (9th Cir. 2007).

${ }^{9}$ See Paladin Associates, Inc. v. Mont. Power Co., 328 F.3d 1145,1159 (9th Cir. 2003).

${ }^{10}$ Jefferson Parish Hosp. Dist. No. 2 v. Hyde, 466 U.S. 2, 12 (1984).

${ }^{11}$ Cascade Health Solutions, at 112, supra at n. 8
} 
U.S. Olympic gold medalist and professional world champion Oscar de la Hoya, Golden Boy Boxing has amassed a successful stable of fighters and it is one of the top promoters in the sport of boxing. It has produced successful pay-perview boxing events as well as having an ongoing cable television contract with Showtime Networks.

\section{Bob Arum Founds Top Rank Boxing}

Top Rank Boxing was founded by former U.S. tax lawyer Bob Arum. Ironically, Arum became the promoter for De La Hoya in the 1990s, but the boxer split ways with Arum in 2002 to create his own promotional company, the aforementioned Golden Boy Promotions. Arum also became the promoter for Manny Pacquiao. The Filipino fighter became one of the most popular fighters in the world during the 2000s. In 2016, Arum promoted the 2,000th event of his career, which highlights being one of the most dominant boxing promoters for most of the last 50 years. ${ }^{12}$ Similar to Golden Boy, Top Rank has put on pay-per-view boxing events and has a cable television deal.

\section{PBC and Al Haymon}

Haymon is Harvard-educated and began in the music business representing such groups as M.C. Hammer, New Edition, Whitney Houston, and Mary J. Blige.13 He moved into television production and then into boxing when he represented boxer Vernon Forrest. His book of boxing business skyrocketed once he became the adviser to Floyd Mayweather, Jr.

In January 2015, Premier Boxing Champions launched as a television boxing series organized by Haymon Sports, LLC. ${ }^{14}$ It was described as "a boxing series that returns the sweet science to its rightful place atop the sports pantheon." 15 In January 2015, NBC Sports Group announced a multi-year agreement to television $\mathrm{PBC}$, marking a return of boxing to major network television with a March telecast. ${ }^{16}$ It would also air on NBC Sports Network. In addition, PBC inked deals with Spike TV, CBS, Fox, Fox Deportes, FS1, Bounce TV, ESPN, and ESPN Deportes.

\footnotetext{
${ }^{12}$ Bill King, Fight for Your Life, SportsBusiness Journal, November 21, 2016, p. 1.

${ }^{13}$ Haymon studied economics and earned an MBA from Harvard, see Greg Bishop, Behind the Scenes - Haymon is Shaking Up the Fight Game, New York Times, December 18, 2011, http:// www.nytimes.com/2011/12/18/sports/behind-the-scenes-haymon-is-shaking-up-the-fight-game. html?_r=1\&pagewanted=all

${ }^{14}$ Premier Boxing Champions, http://www.premierboxingchampions.com/about (last visited January 19, 2018).

${ }^{15} I d$.

${ }^{16}$ PR Newswire, NBC Sports Group Announces Multi-Year Deal for New 'Premier Boxing Champions' Series. January 30, 2015, http://www.prnewswire.com/news-releases/nbc-sports-group-announces-multi-year-deal-for-new-premier-boxing-champions-series-300020583.html
} 
On PBC's website, it states that bouts featured within the PBC Series are promoted by licensed promoters, with each bout in accordance with applicable regulatory rules and regulations..$^{17}$

With the influx of programming on a broad range of networks, PBC dominated the landscape of boxing in 2015. PBC had stormed the market through "time buys" - the strategy implemented for the purchase of time on networks. Allegedly, it was the eventual plan of garnering the networks to license fees at a later yet-to-be-determined date. ${ }^{18}$ The new competition to the boxing market caused perennial top promoters Top Rank and Golden Boy concern. While both Top Rank and Golden Boy had deals with premium networks HBO and Showtime to air events, PBC was squeezing market share (and options) away from the two.

In addition, Golden Boy and Top Rank claimed that Haymon's contracts restricted fighters from taking fights from other promotions. They were forced to work with promoters that Top Rank and Golden Boy claimed worked under the direction of Haymon. Therefore, these promoters did not exercise independent discretion; rather, Haymon was really the promoter with these "sham" promoters acting as mere conduits.

Another result of the Haymon contracts was the allegation that he served in the dual role as manager and promoter for the fighter. This would be in direct violation of the federal law protecting boxers from unethical promoters and managers, the Muhammad Ali Boxing Reform Act.

\section{Revelations about PBC}

An April 2015 feature on Premier Boxing Champions shed light on the business model that sent the boxing world up in arms. ${ }^{19}$ Public documents revealed that Haymon's investors paid NBC over $\$ 425$ million to air PBC on its networks. ${ }^{20}$ The financials for the undertaking include a $\$ 371.3$ million investment by Ivy Asset Strategy Fund, in what King determined to be Haymon Boxing. A second fund, WRA Asset Strategy, listed an investment of \$42.2 million in Haymon Boxing, and a third fund, Ivy Funds VIP Asset Strategy, showed an investment of \$18.5 million. Waddell \& Reed fund manager Ryan Caldwell and Haymon attorney Mike Ring helped facilitate the deal. ${ }^{21}$ The investment in a sports property is not unprecedented, as Caldwell co-managed a fund that put \$1.5 billion into Formula One racing. ${ }^{22}$

\footnotetext{
${ }^{17}$ http://www.premierboxingchampions.com/about, supra at n. 14.

${ }^{18}$ Lance Pugmire, Al Haymon is Spending to Put Boxing on TV, But Do the Numbers Add Up? Los Angeles Times, February 2, 2016, http://www.latimes.com/sports/la-sp-al-haymon-boxing20160203-story.html

${ }^{19}$ Bill King, Boxing's Grand New Stage, SportsBusiness Journal, April 20, 2015, p. 1.

${ }^{20} \mathrm{Id}$.

${ }^{21} I d$.

${ }^{22}$ Mark Scott, CVC Capital Is Said to Have Cut Its Stake in Formula One, New York Times, May 22, 2012, https://dealbook.nytimes.com/2012/05/22/cvc-capital-is-said-to-have-reduced-its-stakein-formula-one/? $\mathrm{r}=0$
} 
The \$432 million and the unique structure of the two-year deal convinced NBC to invest production costs as well as delivering well-known names as on-air talent (i.e., Al Michaels, Bob Costas, Sugar Ray Leonard) to its broadcasts. ${ }^{23}$

The feature served as a marketing piece for Haymon's PBC. It also served as a road map for Golden Boy and Top Rank to file a lawsuit against Haymon. The financial information also may have been news to some investors who filed a lawsuit against the hedge fund for its investment in PBC. ${ }^{24}$

The initial rollout of PBC came with much fanfare and impressive ratings. ${ }^{25}$ Much of the allure was the return of boxing to major network television. The hope would be to introduce boxers to a general public with the intent to create stars outside of the established Floyd Mayweather and Manny Pacquiao.

\section{Golden Boy Boxing Files a Lawsuit Against PBC}

On May 5, 2015, Golden Boy Boxing filed a lawsuit against Al Haymon. ${ }^{26}$ The complaint sought an injunction against Haymon's business practices as well as a sum of $\$ 100$ million plus the statutory damages, which would be three times the amount in its claim ${ }^{27}$ — thus, $\$ 300$ million.

The lawsuit argues that Haymon, Alan Haymon Development, Inc., Haymon Sports, LLC, Haymon Boxing Management, Haymon Boxing LLC, Haymon Boxing Media Group Holdings LLC, Waddell \& Reed Financial, Inc., Waddell \& Reed, Inc., Ivy Asset Strategy Fund, WRA Asset Strategy, Ivy Funds VIP Asset Strategy, and Ryan Caldwell ${ }^{28}$ violated sections 1 and 2 of the Sherman Antitrust Act, the Clayton Act, the Muhammad Ali Act, and California state unfair practices law. Golden Boy breaks down the pro boxing industry into two different parts that comprise two distinct markets: boxing managers and boxing promoters.

\section{Summary of Allegations}

Golden Boy claimed an unlawful "tying" arrangement pursuant to the Sherman Act $\S 1$. Golden Boy accused Haymon of an illegal "tying" relationship between

\footnotetext{
${ }^{23}$ King, supra at n. 19

${ }^{24}$ Jason Cruz, Investors File Lawsuit over PBC Investment, MMAPayout.com, May 5, 2016, http:// mmapayout.com/2016/05/investors-file-lawsuit-over-pbc-investment-by-fund/

${ }^{25}$ Paulsen, PBC Debut Earns Top Boxing Audience in 17 years, www.sportsmediawatch.com, March 10, 2015, http:/www.sportsmediawatch.com/2015/03/premier-boxing-champions-ratingsmost-watched-since-1998-topsrecent-ufc-fox-telecasts/

${ }^{26}$ Compl. for Sherman Act Violation and Unfair Competition, Golden Boy Promotions, LLC and Bernard Hopkins v. Alan Haymon, et al., (hereinafter “Golden Boy Complaint”), filed May 5, 2015, 2:15-cv-03378-JFW-MRW.

${ }^{27}$ Golden Boy Complaint, supra.

${ }^{28}$ For ease of reference, I will refer to these defendants as simply "Haymon" unless specifically referring about an entity.
} 
services sold in the market for management of championship-caliber boxers and the market for promotion of championship-caliber boxers. ${ }^{29}$ Golden Boy claims that Haymon exercised his monopoly power in the market for management of championship-caliber boxers and as a result of the dominance in the "tying" market, it could affect competition in the market for promotion in the "tied" market. Golden Boy claimed that Haymon "locked in" its boxers to deals, which prevented them from fighting for promoters not allowed by Haymon. ${ }^{30}$ This foreclosed competition and "locked in" boxers managed by Haymon.

The second claim in the Golden Boy complaint was a claim under Sherman Act $\S 1$ alleging a conspiracy in restraint of trade. This relates to the claim that Haymon acted as both manager and promoter to gain an unfair advantage over legitimate promoters, entering into "tie out" agreements to prevent championship-caliber boxers from contracting with legitimate promoters of their choice, utilizing "sham" promoters, and using exclusive dealing arrangements to lock up boxing talent, venues, and television networks. Also, Haymon is alleged to have paid broadcast companies for exclusive rights to television air time on most U.S. networks to block other promotions from airing on the same networks.

The third claim alleges a Sherman Antitrust Act $§ 2$ violation claiming predatory and anticompetitive conducts to leverage Haymon's monopoly power in the market for managers of championship-caliber boxers, in an attempt to obtain a monopoly in the market for championship-caliber boxers. The allegations of this third claim include the violation of state and federal acts by acting as both manager and promoter in an effort to gain an advantage over other promoters. Here, California unfair competition law and the federal law in question is the Ali Act, which specifically prohibits promoters from serving as managers and managers serving as promoters. ${ }^{31}$ The alleged scheme mapped out by Golden Boy indicates that Haymon had market power in one business (i.e., management of boxers) to "monopolize another business" (i.e., promoting fights). In this instance, Golden Boy claimed that Haymon locked down a stable of championship-caliber boxers, which prevented them from contracting with promoters aside from Haymon and/ or "sham" promoters who acted in concert with Haymon. While Haymon was not a listed promoter, Golden Boy claimed that these "sham" promoters worked on Haymon's behalf.

\section{Market Definitions}

Golden Boy claimed that the market illegally affected by PBC deals "primarily with 'Championship-Caliber Boxers'- that is professional boxers who, during the last three years, have demonstrated through such factors as purse size,

\footnotetext{
${ }^{29}$ Golden Boy Complaint, at 921 , supra at n. 26.

${ }^{30} \mathrm{Id}$.

${ }^{31}$ See California Business and Professions Code $\$ 17,200$ et seq. and the Muhammad Ali Boxing Reform Act, 15 U.S.C. $§ 6308(b)$.
} 
television rights, viewership, ticket revenue and other objective factors to be 'the cream of the boxing business." ${ }^{32}$

Notably, in the complaint, Waddell (the Haymon investment fund) offered to purchase $100 \%$ of the equity interest in Golden Boy but the transaction was predicated on a "lengthy non-competition agreement from De La Hoya (Golden Boy founder)." 33

This allegation suggests that Waddell, a fund with different assets, was mainly funded by Haymon in order to purchase Golden Boy. The transaction was structured this way in order to "conceal" the identity of Haymon so as not to alert Golden Boy or anyone else of the potential monopoly. ${ }^{34}$

Golden Boy attacked the Haymon "time buys" on the various networks by arguing that it was "patently an act of promotion by a boxing manager." ${ }^{35}$ It also claimed that it has entered into "coercive contracts" with Haymon fighters as fighters must sign "multi-year" contracts with the Haymon defendants.

\section{Loss Leader Strategy}

The scheme claimed by Golden Boy indicated that Haymon was willing to take on losses in the "hundreds of millions of dollars" initially for future gain to control the "promotion of boxing on American network television." ${ }^{36}$ Golden Boy suggested that once they secured its market dominance, it will "reverse the financial arrangements, recoup their losses, pay less to boxers and reap massive profits, far in excess of their temporary losses, by charging supracompetitve prices to networks, sponsors and consumers." 37

\section{Haymon Time Buys}

Golden Boy argued that the time buys "tie out" other promoters from attempting to secure television deals. The issue with the scheme laid out by Golden Boy is that while it may be true that the business strategy by Haymon may be to one day seek to switch its current time buys to network deals in which the networks would pay Haymon, it does not mean it does not violate antitrust laws. ${ }^{38}$

One of the issues Golden Boy points out is that boxing managers negotiate with boxing promoters on behalf of their boxers. The Muhammad Ali Boxing Reform Act creates a "[f]irewall between promoters and managers." ${ }^{39}$ The Ali Act prohibits "a direct or indirect financial interest in the promotion of a boxer" and from being "employed by or receiv[ing] compensation or other benefits from

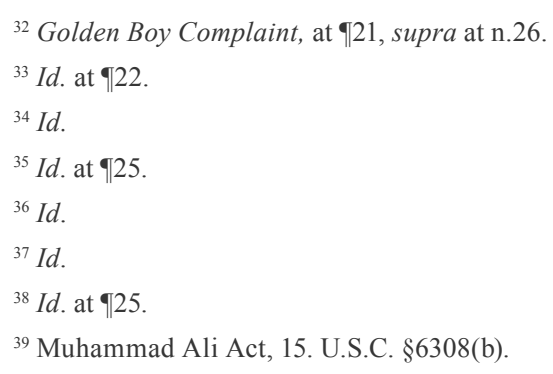


a promoter." ${ }^{40}$ Golden Boy argues that Haymon violated this law by managing fighters without a license in most instances. It also claims that Haymon violated the law as it acts as a promoter. In this capacity, promoters are to make "extensive financial disclosures to state boxing commissions and to boxers, and imposes an obligation on promoters to notify the state boxing commission before any professional boxing match is held." ${ }^{, 41}$ According to the Senate Report that discussed the Ali Act: "It is not plausible for a boxer to receive proper representation and counsel from a manager if the manager is also on the payroll of a promoter. ${ }^{42}$ This is an obvious conflict of interest that works to the detriment of the boxer and the advantage of the promoter." 43 With the alleged scheme, Golden Boy claims that Haymon contracts create an illegal "tying relationship between relationships between services sold in separately defined markets (management and promotion of boxing). ${ }^{44}$

\section{Exclusive Dealing in Boxing Contracts}

The lawsuit claims that Haymon Sports used provisions in contracts in addition to exclusive, multi-year management contracts to preclude boxers from entering into contracts with Golden Boy or other "legitimate" promoters. Instead, the boxers are forced to work with "sham" promoters. The contract that Golden Boy alleged was exclusionary states:

(ii) Fighter Actions. From and after the Effective Date and continuing for the duration of the Term, Fighter shall not (directly or indirectly) enter into any agreement or arrangement (written or verbal), or grant any authority or power, relating to any Boxing Activities, without the prior written consent of Manager, subject to applicable law.

\section{And}

(iii) Promotional Agreements. If during the Term hereof, Fighter desires to enter into any promotional agreement or bout agreement to which Fighter is not then bound, selection of the promoter shall be at the sole discretion of the Manager. ${ }^{45}$

The contractual language was waived in its settlement agreement with Top Rank, which resulted in a dismissal of that case. ${ }^{46}$

\footnotetext{
${ }^{40} I d$.

${ }^{41}$ Golden Boy Complaint, supra at n. 26.

${ }^{42} I d$.

${ }^{43} \mathrm{Id}$. at 918 .

${ }^{44} \mathrm{Id}$.

${ }^{45}$ Order Granting Def. Alan Haymon's Mot. for Summ. J. (hereinafter "Golden Boy Dismissal”), Golden Boy, et al. v. Haymon, et al., January 26, 2017, p. 3, ECF No. 339.

${ }^{46} I d$. at p. $3, \mathrm{FN} 3$.
} 
Notwithstanding the concession of the issue with respect to exclusive dealings, Golden Boy and Haymon geared for a March 17, 2017, trial date.

A noteworthy side issue was the settlement agreement executed by the parties in a previous business relationship with Golden Boy. As part of the agreement, Golden Boy surrendered its promotional rights to a number of top boxers who were signed with Haymon as their manager. ${ }^{47}$ Haymon attempted to push the Golden Boy case into arbitration, citing this settlement agreement. ${ }^{48}$ According to the terms of the settlement agreement between Golden Boy and Haymon signed on December 19, 2014, it was exercised by Haymon on January 8, 2015.49 According to Haymon, it was a "global" settlement of all issues between the parties ${ }^{50}$ Haymon made "a substantial payment to Golden Boy," which Golden Boy accepted when the parties decided to end its business relationship. ${ }^{51}$ The settlement includes an arbitration provision that would require that the parties be subject to an arbitrator rather than litigate the matter in court. Haymon's attorneys argued that the date of its federal claims on January 1, 2015, was a way to circumvent this settlement agreement. ${ }^{52}$ Eventually, the lawsuit was allowed to go forward without arbitration. But, the date of January 1, 2015, was relevant to the dates in which there could be a finding of alleged antitrust injury.

Haymon defended two large antitrust lawsuits at the same time with the Top Rank lawsuit occurring simultaneously as the Golden Boy lawsuit. As explained in more detail later in this paper, Haymon navigated the Top Rank lawsuit with some damage, but the parties came to a settlement prior to going to trial. Having settled the Top Rank case, it sought to move for a summary judgment of Golden Boy's claims.

\footnotetext{
${ }^{47}$ Kevin Iole, Golden Boy, Richard Schaefer Settle, GBP Parts Way with Most Al Haymon Fighters, Yahoo! Sports, January 9, 2015, http://sports.yahoo.com/blogs/boxing/golden-boy--richardschaefer-settle--gbp-parts-way-withmost- al-haymon-fighters-020545902.html

${ }^{48}$ Defs.' Notice of Mot. and Mot. Stay Action Pending Arbitrator's Decision on Arbitrability and Release of Claims; Mem. of Points and Authorities in Support Thereof; Decls. of Alan Haymon and Jeremiah Reynolds in Support Thereof, Golden Boy, et al. v. Haymon, et al., CV 15-3378JFW, July 6, 2015, ECF No. 22.

${ }^{49}$ Settlement and Release Agreement affixed to Decl. of Alan Haymon ("Haymon Decl.") at 93 attached to Notice of Mot. and Mot. Stay Action Pending Arbitrator's Decision on Arbitrability and Release of Claims; Memo. of Points and Authorities in Support Thereof; Decls. of Alan Haymon and Jeremiah Reynolds in Support Thereof, Golden Boy, et al. v. Haymon, et al., CV 15-3378JFW, July 6, 2015, ECF No. 22.

${ }^{50}$ Haymon Decl., supra at n. 43, Haymon Arbitration Brief, infra.

${ }^{51}$ Haymon Arbitration Brief, infra.

${ }_{52}$ Opening Brief Regarding Arbitrability and Release of Claims, ("Haymon Arbitration Brief") at p. 2, Golden Boy, et al. v. Haymon, et al., 2:15-cv-03378-JFW-MRW, July 6, 2015.
} 


\section{The Court Grants Summary Judgment}

In October 2016, Haymon filed a motion for summary judgment to dismiss Golden Boy's claims. Originally, the Court was to hear oral arguments but decided to issue a ruling based upon the pleadings. ${ }^{53}$ In a 28-page opinion, the Court granted Haymon's motion for summary judgment. "After conducting substantial discovery, Plaintiffs have been unable to present any evidence of harm to competition. Instead, Plaintiffs have merely presented evidence of harm to themselves," wrote the Court. ${ }^{54}$ In the Court opinion's conclusion, it stated a reminder that the antitrust laws protect competition, not competitors. ${ }^{55}$

The Court dismissed Golden Boy's complaint as finding no genuine issues of material fact. In the dismissal, the Court did away with Golden Boy's claim of an unlawful "tie out" in violation of Section 1 of the Sherman Act and for attempted monopolization in violation of Section 2 of the Sherman Act.

Golden Boy defined the claimed monopolized markets as controlled by Haymon as the management and promotion of elite boxers in the United States. ${ }^{56}$ Haymon disputed the definitions of the markets taking issue with Golden Boy's expert opinion, which included a failure to provide hypothetical market replacements and the elasticity of the relevant markets. ${ }^{57}$

In looking at the dismissal of Golden Boy's Section 1 of the Sherman Act for tying, the Court concluded that Golden Boy failed to demonstrate that Haymon tied together the sale of two products. While illegal tying arrangements need not be expressed, and "consent" clauses may practically function as unlawful tying arrangements, the Court did not find this to be the case. One of the fatal flaws for Golden Boy was that no boxer submitted testimony claiming a tie arrangement and that they were pressured or coerced into working with a particular promoter (i.e., "sham" promoter) as outlined by Golden Boy. ${ }^{58}$ In contrast, Haymon submitted the declarations of six boxers who stated that they were never pressured or coerced to work with any particular promoter or not work with any particular promoter. Furthermore, the Court notes that Haymon's boxers have worked with other promoters including a fight between Golden Boy and rival Top Rank. Also, the fight between Floyd Mayweather and Manny Pacquiao was an inter-promotional matchup.

The issue of extensive contracts was addressed by the Court as Golden Boy argued that Haymon fighters were held to exclusive agreements that prevented them from working with other promoters and fighting non-Haymon fighters. In the opinion, the Court sides with Haymon's viewpoint on long contracts. It

\footnotetext{
${ }^{53}$ Order Taking Under Submission Def. Alan Haymon's Mot. for Summ. J., Golden Boy, et al. v. Haymon, et al., CV15-3378-JFW (MRWx), November 21, 2016, ECF No. 304.

${ }^{54}$ Golden Boy Dismissal, supra at n. 45.

${ }^{55} I d$.

${ }^{56} I d$.

${ }^{57}$ Def. Alan Haymon's Not. of Mot. and Mot. for Summ. J., p. 16-25, Golden Boy, et al. v. Haymon, et al., CV 15-3378-JFW(MRWx), October 31, 2016, ECF No. 158.

${ }^{58}$ Golden Boy Dismissal, p. 6, supra at n. 45.
} 
acknowledged that Golden Boy does not work with many Haymon-managed fighters despite the market share of Golden Boy due to the fact that the promotion favors long-term promotional agreements. Haymon is against such deals because he believes they "primarily benefit the promoter." Here, the Court determined that the disparity between Golden Boy and Haymon was not based on an illegal tying but a market-based explanation. ${ }^{59}$ Here, it was the choice of not agreeing to the terms as being the reason for not dealing with another rather than an illegal act.

Next, Golden Boy's lack of evidence that Haymon turned down a proposed fight to Haymon Sports at the time covered by the lawsuit is another reason its lawsuit failed. Golden Boy's claim that a proposed fight offer would have been futile was not accepted by the Court as it looked to previous inter-promotional matchups between the two companies. Certainly, an offer, even one with the knowledge that it would be denied, could have saved Golden Boy here. But, as a result, Golden Boy failed to demonstrate that management contracts practically function as unlawful tying arrangements.

The Court was not convinced with the defining market asserted by Golden Boy in its claims against Haymon. Clearly, "without a definition of the relevant market, it is impossible to determine market share." ${ }^{60}$ This must include a relevant product market and a geographic market. The product market must include the product at issue as well as all economic substitutes for the product. The geographic market extends to the area of effective competition, where buyers can turn for alternative sources of supply. ${ }^{61}$ The Court found "fundamental flaws" in Golden Boy's expert opinion regarding the tying product market. ${ }^{62}$ Specifically, 1) the product market failed to encompass all economic substitutes of the product and 2) the geographic market failed to extend to the area of effective competition where buyers can seek alternative sources of supply. ${ }^{63}$

The first problem identified by the Court was that Golden Boy's economics expert, Dr. Robert Kneuper, did not examine the market for managers and assess the interchangeability with potential substitutes. The Court acknowledged that this is a requisite in defining the market. Instead, the Court stated that the analysis only includes those within the championship-caliber boxing market. This is problematic considering the hypothetical that managers of non-championship-caliber boxers can become managers of championship-caliber boxers as the result of a single fight. The opinion referred to a case of a relatively obscure boxer, Joe Smith, and an upset win over title contender Andrzrej Fonfara that propelled Smith from non-contender to one considered a championship-caliber boxer. ${ }^{64}$

\footnotetext{
${ }^{59}$ See It's My Party, Inc. v. Live Nation, Inc. 811 F.3d 676, 683 (4th Cir. 2016).

${ }^{60}$ See Rebel Oil Company v. Atlantic Richfield Company, 51 F.3d 1421, 1434 (9th Cir., 1998).

${ }^{61}$ See Tanaka v. University of S. California, 252 F.3d 1059, 1063 (9th Cir. 2001).

${ }^{62}$ Golden Boy Dismissal, p. 13, supra at n. 45.

${ }^{63} \mathrm{Id}$.

${ }^{64}$ Keith Idec, BoxingScene Upset of the Year: Joe Smith KO's Andrzej Fonfara, December 30, 2016, http://www.boxingscene.com/boxingscene-upset-year-joe-smith-knockout-andrzej-fonfara--112206
} 
As a result, Smith's manager became a manager of championship-caliber. This example highlighted the problems the court found with this examination, which rendered the product market asserted by Golden Boy unsustainable.

Moreover, the geographic market fails to consider alternative sources of supply in the event of a significant non-transitory increase in price ("SSNIP") by a hypothetical monopolist. ${ }^{65}$ Golden Boy's expert limits the management market to U.S.-based managers. As such, Kneuper does not consider managers outside the relevant market despite the possibility of managing a championship-caliber boxer. Kneuper attempted to clarify his position at his deposition but the Court found he did not support his conclusions with any empirical data. ${ }^{66}$

Based on the information set forth, the Court held that Golden Boy was unable to define the relevant market in its claim against Haymon. Thus, Golden Boy could not prove Haymon had a substantial share of a properly defined market. Moreover, Golden Boy neglected to address its barriers to entry in the market.

First, it cited the fact that to become a manager, the only barrier would be a fee-based application that ranges from $\$ 30$ to $\$ 100$ in most states and the likelihood of a background check. ${ }^{67}$ Of course, relatives, friends, trainers, former fighters, attorneys, and others manage boxers. ${ }^{68}$ Golden Boy argued that the barriers to entry require "industry experience, knowledge of boxing and its key players as well as the rules and regulations governing the sport and the economic factors that go into negotiating boxing contracts for top level boxers." ${ }^{\prime 69}$ The Court did not believe this barrier to be significant and did not believe that it would economically impact entry into the market.

Rather than focusing on the economic barriers to entry, Kneuper emphasized the "network effects" as a barrier to entry. A "network effect" exists when "desired behavior of an individual depends on some average action of others." The Court determined that this theory erroneously assumes that PBC already operates as a league, in which only Haymon-managed boxers fight other Haymon-managed boxers, and that only Haymon-managed boxers appear on PBC. The Court points to an Al Haymon declaration in which he states that "a third of the boxers who have competed in the PBC series are not managed or advised by Haymon Sports." ${ }^{71}$ Golden Boy has not provided any evidence that managers have found it difficult to enter the management market in recent years.

\footnotetext{
${ }^{65}$ Golden Boy Dismissal, supra at n. 45.

${ }^{66} I d$. at $\mathrm{FN} 18$.

${ }^{67} \mathrm{Id}$. at 15 .

${ }^{68}$ Id. See also, Decl. of Eric Gomez (“Gomez Decl.”) at 35; Gomez Dep. 56:3-57:16; Cameron Dep. 109:13-18; 109:24-111:3.

${ }^{69}$ Plaintiffs' Points \& Authorities in Opp'n to Def. Haymon's Mot. for Summ. J. at p. 23, 2:15-cv-03378-JFWMRW, November 9, 2016, ECF No. 215.

${ }^{70}$ Id. See also Kneuper Report at 92 supra n. 26.

${ }^{71}$ Al Haymon Decl. in support of Haymon’s Mot. for Summ. J., etc. at $₫ 18$ supra at 57.
} 
In its final argument regarding barriers to entry, the Court notes that the purported five-year exclusive management contract is not proven to be an industry standard.

The Court determined that based on the lack of a justifiable market definition and the showing of a significant barrier to entry with respect to the management market, Golden Boy did not present a genuine issue of material fact regarding Haymon's market power.

The Court denied Golden Boy's claim that Haymon attempted to obtain a monopoly in the market for promoting bouts of championship-caliber boxers in violation of Section 2 of the Sherman Act. ${ }^{72}$ Specifically, the claim rejected that Haymon entered into unlawful "tying" or "tie out" arrangements, whereby preventing championship-caliber boxers from contracting with Golden Boy or with other "legitimate" promoters; entered into exclusive agreements with television networks and boxers; participated in venue blocking and predatory pricing; and violated the Ali Act.

The Court did not find Haymon's PBC exclusive television agreements as anticompetitive. ${ }^{73}$ It identified "existing and potential alternative channels" for Golden Boy. The Court noted that HBO, Showtime, and pay-per-view outlets were available to other promoters as PBC did not have exclusivity arrangements with those outlets. ${ }^{74}$ It also asserts the opportunity of "potential alternative channels" of distribution in the market. ${ }^{75}$ Essentially, the Court notes the possibility of other channels to air boxing (including English and Spanish) rather than those airing PBC.

Secondly, with respect to its "venue blocking" argument that Haymon "locked up" desirable dates in major arenas to prevent Golden Boy and other promoters from holding events in the venue, the Court did not find evidence to support this claim. Similar to the exclusive television agreements, the Court looked at the issue under the rule of reason analysis. Under this examination, there was just one venue that was "locked up" and no other examples offered by Golden Boy. Moreover, the Court notes the "numerous alternative venues" in most cities in the US, which makes this argument a non-sequitur.

Third, in addressing Golden Boy's "predatory pricing” scheme with respect to its "loss leader" strategy of buying air time on networks while incurring large financial losses in hopes of recouping the losses at a later date, the Court found no evidence. Again, Golden Boy's expert did not perform a "recoupment analysis," which would examine how Haymon planned to recover the money it invested in time buys. In fact, the Court states that Haymon has suffered severe losses. ${ }^{76}$

\footnotetext{
${ }^{72}$ Golden Boy Dismissal, supra at n. 45.

${ }^{73} \mathrm{Id}$.

${ }^{74} I d$.

${ }^{75} \mathrm{Id}$.

${ }^{76}$ See also, Paul Gift, Alleged Investments into PBC's Al Haymon Plummet \$434 Million in a Single Year, BloodyElbow.com, September 20, 2016, http://www.bloodyelbow. com/2016/9/20/12983690/waddell-reedinvestments-434-million-decline-al-haymon-pbc-boxingnews
} 
The final argument in the Section 2 claim was the alleged injury in violation of the Ali Act. As pointed out by the Court, there must be an "antitrust injury." But, only boxers or government agencies can assert a violation of the Ali Act. ${ }^{77}$

\section{Top Rank Boxing Sues PBC}

On July 1, 2015, Top Rank sued Al Haymon and Waddell \& Reed Financial in the U.S. District Court for the Central District of California in Los Angeles. ${ }^{78}$ The Top Rank lawsuit was patterned after Golden Boy's lawsuit. It claimed that Haymon and his business holdings violated antitrust laws including Sherman Antitrust $\S 1$ and $\S 2$, the Muhammad Ali Act, and California state unfair competition law.

Top Rank claimed that Haymon sought to "buy up and monopolize the entire vertical channel" of top fighters, "tying out" promoters, excluding promoters from major venues, and using its "time buy" strategy as a "predatory 'payola' scheme." The lawsuit stated that Top Rank's losses could exceed \$200 million in PBC's first two years in existence.

Specifically, Top Rank alleged that Haymon violated Section 1 of the Sherman Act as it relates to unreasonable restraints of trade and tying. It also claimed a violation of Section 2, which governs attempted monopolization. Featured in the lawsuit was the discussion of the passage of the Ali Act including major reforms such as a "firewall" between managers and promoters prohibiting managers from being or working for a promoter, protection from coercive contracts, and providing boxers with financial disclosures regarding the bouts they promote. The Ali Act was central to Top Rank in its lawsuit.

Similar to the Golden Boy lawsuit, the issue of "sham promoters" was discussed as Top Rank claimed that Haymon worked with regional promoters that knew the area and paid them a fee to operate shows. While they promoted the events, it was clear, according to Top Rank, that the decisions on ticket prices and presentation was up to Haymon. Additionally, Top Rank argued that Haymon engaged in "venue blocking" where he allegedly used his dominant position in the management market to obtain favorable dates at venues. Top Rank claimed that Haymon reserved several venues to prohibit fights promoted by others. Additionally, Top Rank claimed that it had "significant power in negotiating with venues." It also exerted its alleged dominance in the promoter market to secure exclusive contracts with television networks that would thereby foreclose other promotions to work with these networks.

The complaint sought $\$ 100$ million in damages. Top Rank filed a first amended complaint on August 3, 2015. ${ }^{79}$ On August 31, 2015, Haymon filed a

\footnotetext{
${ }^{77}$ See 15 U.S.C. $\$ 6309$ (a).

${ }^{78}$ Compl. for Violations of Sherman Act and California Unfair Competition Law (hereinafter Top Rank Complaint), Top Rank, Inc., v. Al Haymon, et al. case 2:15-cv-04961-JFW-MRW, July 1, 2015, ECF No. 1.

${ }^{79}$ First Am. Compl. for Violations of Sherman Act and California Unfair Competition Law, Top Rank, Inc., v. Al Haymon, et al., case 2:15-cv-04961-JFW-MRW, August 3, 2015, ECF No. 40.
} 
motion to dismiss. ${ }^{80}$ Haymon argued that Top Rank's first amended complaint failed to adequately plead antirust injury, failed to adequately define relevant markets, and failed to adequately allege market power and impermissible reliance on group pleading.

In the most basic of arguments, Haymon argued that there was no "antitrust injury." 81 In its order dismissing its claims, the Court sided with Haymon. The Court noted that Top Rank "has not identified a single bout that it has attempted to promote but was precluded from promoting by the Haymon Defendants, a single venue from which it has been blocked, or a single network that has refused to broadcast a fight promoted by Top Rank." 82 The Court did not find Top Rank provided any evidence in which the promotion has actually been "frozen out" by any conduct by Haymon.

As for its "tie out" argument, the Court was not persuaded with single instances of purported "tie out" practices in its lawsuit. The Court noted the "alleged actions may not have affected all promoters equally, may not have affected certain promoters at all, and in fact, may have even helped certain promoters." ${ }^{83}$ The evidence provided by Top Rank did not sway the Court in determining whether there was an antitrust injury and whether that injury, if any, flowed from that which makes the conduct unlawful.

In addition, the Court did not believe that Top Rank properly defined the relevant markets. Here, Top Rank did not properly allege both "that a 'relevant market' exists and that the defendant has power within that market." ${ }^{\text {" }}$ The Court held that Top Rank's definition of the relevant markets survive the pleading stage; however, Top Rank failed to adequately allege market power or economic power within those markets. For a Sherman Act claim to succeed, the plaintiffs needed to show market power within the defined markets. The Court characterized Top Rank's allegations of Haymon's market power as "disconnected" from the relevant market definition.

Top Rank identified two relevant markets: 1) the market for the management of championship-caliber boxers in the US and 2) the market for the promotion of championship-caliber boxers in the US. The definition provided by Top Rank for "championship-caliber boxers" are "professional boxers who, within the past three years, have demonstrated through such quantitative factors as purse size, television rights, viewership, ticket revenue, and other objective criteria that they

\footnotetext{
${ }^{80}$ The Haymon Defendants' Notice of Mot. and Mot. to Dismiss Pursuant to FRCP 12(b)(6); Mem. of Law in Support of Their Mot. to Dismiss The First Am. Compl., ("Haymon Motion to Dismiss"), Top Rank, Inc., v. Al Haymon, et al., Case No. CV 15-04961-JFW(MRWx) filed August 31, 2015, ECF No. 61.

${ }^{81}$ See Atl. Richfield Co. USA Petroleum Co., 495, U.S. 328, 334 (1990).

${ }^{82}$ Haymon Mot. to Dismiss, supra at n. 57; Order Granting in Part the Haymon Defs' Mot. to Dismiss Pursuant to FRCP 12(b)(6), at p. 7, Top Rank, Inc., v. Al Haymon, et al., infra at n. 86.

${ }^{83} \mathrm{Id}$.

${ }^{84}$ Id., See also Newal Indus., Inc. v. Ikon Office Sol, 513 F.3d 1038, 1044 (9th Cir. 2008).
} 
belong to the 'cream' of the boxing business. ${ }^{85}$ The Court concluded that Top Rank failed to allege that Haymon possessed market power or economic power in either of the relevant markets. It was confused with Top Rank's allegations that Haymon had market power over the management market, while the relevant market is for the management of championship-caliber boxers in the US. But, Top Rank alleged Haymon had a "dominant share" of a market not limited to championship-caliber boxers. Additionally, it was left guessing as to how Top Rank came to the conclusion that Haymon's share of the relevant market "is greater than $50 \%$." 86

On October 16, 2015, the Honorable John F. Walter granted Haymon's motion. ${ }^{87}$ Judge Walter determined the motion without oral argument. ${ }^{88}$

The Court found no tying arrangement pursuant to Section 1 of the Sherman Antitrust Act. "To accomplish this objective, the competitor agrees 'to sell one product (the tying product) but only on the condition that the buyer also purchase a different product (the tied product), or at least agrees that he will not purchase the tied production from any other supplier." "89 A per se violation of Section 1 of the Sherman Act is established if "(1) the defendant tied together the sale of two distinct products or services; (2) the defendant possesses enough economic power in the tying product market to coerce its customers into purchasing the tied product; and (3) the tying arrangement affects a 'not insubstantial volume of commerce' in the tied product market." 90 Top Rank failed to adequately allege that Haymon possessed market or economic power in the management market and failed to allege injury to itself. Also, the Court was not swayed that Haymon tied together the sale of two distinct services. Specifically, it looked at the purported oppressive contractual language in fighter agreements. Contrary to Top Rank's argument, this "consent" provision does not, on its face, tie two services together (management services and promotion services). ${ }^{91}$

Top Rank's claim for violation of Section 2 of the Sherman Act also failed according to the Court. There were no facts supporting Top Rank's claim that Haymon had a monopoly over the promotion market. There were no allegations of facts regarding Haymon's economic power in the promotion market and it does not meet the lower threshold pursuant to Section 2.

\footnotetext{
${ }^{85}$ First Am. Compl. for Violations of Sherman Act and California Unfair Competition Law, Top Rank, Inc., v. Al Haymon, et al., 2:15-cv-4961-JFW-MRW, at \104, August 3, 2015, ECF No. 61.

${ }^{86}$ See Order Granting in Part the Haymon Defs ' Mot. to Dismiss Pursuant to FRCP 12(b)(6), Top Rank, Inc., v. Al Haymon, et al., 2:15-cv-4961-JFW-MRW, August 31, 2015, ECF No. 60.

${ }^{87} I d$ at p. 13.

${ }^{88}$ The order also dismissed Top Rank's antitrust claims on the grounds that Top Rank's allegations draw no meaningful distinctions between or among the nine defendants against whom they are collectively asserted. $I d$. at p. 10.

${ }^{89}$ Id., See Paldin Assocs., Inc. Mont. Power Co., 328 F.3d 1145, 1159 (9th Cir. 2003) (quoting Eastman Kodak Co. v. Image Tech. Servs., Inc., 504 U.S. 451, 461 1992)).

${ }^{90}$ Paladin Assocs, supra at 1159 (citing Eastman Kodak, 504 U.S. at 461-62).

${ }^{91}$ See Midwestern Waffles, Inc. v. Waffle House, Inc., 734 F.2d 705, 712 (11th Cit. 1984).
} 
The Court held that Top Rank's first amended complaint was devoid of any factual allegations demonstrating that the consent clause functioned, in practice, as a tying arrangement or "tie out," at least with respect to Top Rank.

Despite the dismissal, the Court allowed Top Rank the opportunity to refile a second amended complaint. Top Rank did file a second amended complaint on October 30, 2015. The second amended complaint provided more details, including specific names of boxers and how Haymon had allegedly violated antitrust laws. The parties decided to settle the case before expending further legal costs. As a result of the settlement, Haymon conceded exclusivity agreements with television networks and other promotions could air on the same channel as PBC.92

\section{Background on the UFC}

The UFC has grown from being an unregulated oddity to a mainstream sport that was purchased for $\$ 4$ billion in July 2016. Also in 2016, the UFC was legalized in New York state, which it had long-valued as a big step into cementing its spot as a valuable sports commodity. Purchased by Lorenzo and Frank Fertitta for \$2 million in 2001, Zuffa, LLC ("Zuffa") was established as the parent company to run the UFC.

Zuffa fought off huge debt issues to become a profitable organization..$^{93}$ The Fertittas sunk \$38 million into the brand to help it succeed.$^{94}$ Its seminal moment came when it spent millions of dollars to produce a reality TV show called "The Ultimate Fighter," which was aired on the Spike TV network. ${ }^{95}$ It drew rave ratings, especially within the valuable 18 to 34 -year-old demographic. While the ascension of the company can be seen as a success, fighter discontent grew. Zuffa offered bonuses, insurance, and other perks to its contracted fighters, but as independent contractors, Zuffa did not have to offer fighters other benefits that normal employees would receive. Additionally, the compensation for fighters appeared arbitrary and depressed in comparison to the amount of revenue that the UFC began to earn. As the company expanded, issues such as the use of one's image and intellectual property rights in video games and other media came to a head.

\footnotetext{
${ }^{92}$ Notably, Golden Boy secured a television deal with ESPN as announced in January 2017, and set to air on the network in March 2017. See Dan Rafael, Golden Boy Boxing on ESPN Begins Partnership in March, ESPN.com, January 19, 2017, http://www.espn.com/boxing/story/_id/18508305/ golden-boy-promotions-espn-enter-partnership-42-fight-cards-next-two-years

${ }^{93}$ Matthew G. Miller, Fertitta Brothers Turn Ultimate Fighting Championship into a Juggernaut, Washington Post, August 8, 2012, https://www.washingtonpost.com/business/fertitta-brothers-turn-ultimate-fighting-championshipinto-a-juggernaut/2012/08/10/eb88c618-e007-11e1-a19cfcfa365396c8_story.html?utm_term $=.90757 \mathrm{cc} 7 \mathrm{a} 8 \mathrm{f} 8$

${ }^{94}$ Id .

${ }^{95}$ Id.
} 


\section{Former UFC Fighters File Suit Against the UFC}

On December 16, 2014, three former UFC fighters filed a lawsuit against Zuffa operating as Ultimate Fighting Championship and UFC in the United States District Court for the Northern District of California, San Jose Division. ${ }^{96}$ The lawsuit claimed that the UFC had a monopoly and a monopsony over contracted UFC fighters. ${ }^{97}$

The filing of the lawsuit came with an official press conference announcing the filing of the lawsuit. ${ }^{98}$ At the press conference, one of the fighters' attorneys, Benjamin Brown, stated, "The UFC was built on the battered bodies of MMA fighters who have left their blood and sweat in the Octagon. Those fighters are entitled to the benefits of a competitive market for their talents." 99 The lawsuit claimed that the UFC's alleged anti-competitive acts established the company as the only option for MMA fighters who want to earn a viable living in the profession. ${ }^{100}$

The lawsuit claimed that the UFC pursued an aggressive strategy of depriving key inputs to potential rival promoters or merging with them to maintain its monopoly position. It also stated that the UFC implemented an "exclusionary scheme" to impair and foreclose competition, whereby the UFC deprives potential competitors in the fight promotion market access to elite MMA fighters, premium live event venues, and sponsors.

Among the chief complaints from the fighters was that the UFC was able to suppress compensation of its contracted fighters. The lawsuit alleged that fighters were paid "approximately 10-17\%" of total UFC revenues generated from bouts. It also called into question several clauses in the standard UFC fighter contracts, including the "Champions Clause" (allowing UFC to extend a champion's contract for as long as they are champion), the "Right to Match Clause" (allowing the company to match another promotion's offer of services and thereby retaining the fighter), an "Ancillary Rights Clause" (granting the UFC exclusive and perpetual worldwide identity rights of contracted athlete), and the "Sponsorship and Endorsement Clause" (allowimg UFC sole discretion on approving sponsors and endorsement of fighters). ${ }^{101}$

\footnotetext{
${ }^{97}$ After the initial filing by the three former UFC fighters (Cung Le, Nate Quarry, and Jon Fitch), three more (Brandon Vera, Javier Vazquez, and Kyle Kingsbury) filed their own lawsuits and they became consolidated in the one filing, Le Antitrust Compl.

${ }_{98}$ Jason Cruz, Le, Quarry and Fitch File Lawsuit Against Zuffa, MMAPayout.com, December 16, 2014, http://mmapayout.com/2014/12/le-quarry-and-fitch-file-lawsuit-against-zuffa/

${ }^{99}$ Press release, Mixed Martial Arts Fighters File Class-Action Lawsuit Against Ultimate Fighting Championship Alleging Illegal Market Monopolization, December 16, 2014, http://www.cohenmilstein.com/update/mixed-martialarts-fighters-file-class-action-lawsuit-against-ultimate-fighting-championship

${ }^{100} I d$.

${ }^{101}$ Le Antitrust Compl., p. 86, supra at n. 96.
} 


\section{Zuffa's Motion to Dismiss}

Attorneys for Zuffa brought a motion to dismiss the lawsuit. ${ }^{102}$ Zuffa argued that the plaintiffs' allegations were vague and conclusory and did not meet the requirements for showing a plausible antitrust claim. ${ }^{103}$ In its motion, Zuffa argued that its business methods were pro-competitive. It outlined the five key issues in the plaintiffs' lawsuit and detailed why its approaches do not violate the Sherman Act.

First, Zuffa claims that its alleged exclusive dealing arrangements are common and procompetitive "because they encourage interbrand competition, encourage promoters to invest in marketing both the athlete and the sport, and prevent competitors from free-riding on those investments." 104 It argued that the plaintiffs' allegations of Zuffa contracts locking in fighters to the UFC is not supported with specific factual allegations and lack foundation.

Second, it attacks the plaintiffs' definition of the relevant product markets claiming it "invented" the "Elite Professional MMA Fighter" designation and only provided "vague and subjective perceptions of fighters' degrees of quality." "105 Key in the lawsuit is to show that Zuffa possesses monopoly power in a properly defined relevant market. ${ }^{106}$ Zuffa cites Apani Sw., Inc. v. Coca-Cola Enters., Inc., for the supposition that where plaintiffs fail "to define its proposed relevant market with reference to the rule of reasonable interchangeability and cross-elasticity of demand, or alleges a proposed relevant market that clearly does not encompass all interchangeable substitute products even when all factual inferences are granted in plaintiff's favor, the relevant market is insufficient."107

Third, Zuffa argues that allegations against the UFC for refusing to co-promote events is not a recognizable antitrust claim. Moreover, Zuffa's contractual restrictions on the use of the UFC name and brand are not antitrust claims. Zuffa claimed that its business tactics are valid and that it has no duty to deal with competitors or grant use of its intellectual property. ${ }^{108}$

\footnotetext{
${ }^{102}$ Attorneys for the UFC successfully transferred the venue of the case from federal court in Northern California, to federal court in Las Vegas, Nevada. See Order Granting Def.'s Mot. to Transfer Venue, Le, et al. v. Zuffa, LLC, Case Nos. 5:14-cv-05484-EJD; 5:14-cv-05591-EJD; 05:14-cv-05621-EJD; 5:15-cv-00521-EJD; 5:15-cv-01324-EJD, June 2, 2015, ECF No. 93.

${ }^{103}$ Def. Zuffa, LLC's Consolidated Notice of Mot. and Mot. to Dismiss Pls' Compls. Pursuant to Fed. R. Civ. P. 12(b)(6) ("Zuffa LLC's Motion to Dismiss"), Le, et al. v. Zuffa, LLC, Case No. 5:14cv-05484 EJD, February 27, 2015, ECF No. 64.

${ }^{104}$ Id. at p. 11.

${ }^{105}$ Id. at p. 12.

${ }^{106} I d$.

${ }^{107}$ See Apani Sw., Inc. v. Coca-Cola Enters., In., 300 F.3d 620, 628 (5th Cir. 2002) (citing Queen City Pizza, Inc. v. Domino’s Pizza, Inc. 124 F.3d 430, 436 (3d. Cir. 1997)).

${ }^{108}$ Zuffa, LLC's Motion to Dismiss, p. 12, supra at n. 103.
} 
Fourth, rebutting the plaintiffs' claims that their name and likenesses rights were taken from them in Zuffa fight contracts, Zuffa claims that there are no facts that suggest that this is anticompetitive. Instead, Zuffa states that the plaintiffs' claim is "no more than a complaint that they believe they contracted away too many rights for too little compensation." 109 Zuffa cites examples of athletes or performers granting publicity rights as procompetitive.

Fifth, it argued that the plaintiffs did not support their contention that the UFC's acquisition of rival organizations resulted in any anticompetitive effect. ${ }^{110}$ Similar to Haymon's argument in the Top Rank and Golden Boy lawsuits, Zuffa argued that the former fighters could not plead specific facts showing that the exclusivity provisions in Zuffa's contracts are anticompetitive.

The plaintiffs argued that it sufficiently pled that the UFC has monopoly and monopsony power. The plaintiffs state that it plead circumstantial evidence of market power by alleging (1) a market for elite MMA events; (2) the UFC's dominant market share; and (3) barriers to entry. It cites the International Boxing Club of New York, Inc. v. U.S. ${ }^{111}$ case regarding past distinction between "elite and "non-elite" athletes. In that Supreme Court case, the Court affirmed a market limited to "championship" boxing contests rather than all professional boxing contests. ${ }^{112}$

Despite the claim that the elite MMA fighter market is made up, the plaintiffs contend that the distinction between "elite" and "non-elite" fighters is "well understood in the industry." 113

\section{Court Denies Motion to Dismiss}

Judge Richard Boulware issued an order denying Zuffa's motion to dismiss. ${ }^{114}$ In the Court opinion, it dissected Zuffa's motion to dismiss in denying its request to dismiss the plaintiffs' case. The sections the Court addressed were as follows:

\section{Strong Competition v. Antitrust Violation}

This argument was quickly dismissed by the court. Essentially, Zuffa argued that its business practices are examples of "strong competition" whereas the plaintiffs argue that Zuffa's conduct "has foreclosed competition and thereby enhanced and maintained the UFC's monopoly power in the Relevant Output Market and

\footnotetext{
${ }^{109}$ Id. at p. 29.

${ }^{110} I d$.

${ }^{111}$ See International Boxing Club v. United States, 358 U.S., 242, 250-52(1959).

${ }^{112}$ Zuffa LLC's Motion to Dismiss, supra at n. 103.

${ }^{113}$ Pls.' Opp'n to UFC's Motion to Dismiss, at p. 14, Le, et al. v. Zuffa, supra April 10, 2015, ECF No. 69.

${ }^{114}$ Judge Richard Boulware's Order, case 2:15-cv-01045-RFB-PAL, Filed October 19, 2016; see also, Kat Greene, No Quick KO for UFC in Fighters' MMA Monopoly Suit, Law360.com, September 28, 2015, https://www.law360.com/articles/708038/no-quick-ko-for-ufc-in-fighters-mmamonopoly-suit104
} 
monopsony power in the Relevant Input Market." For purposes of meeting the threshold to satisfy a motion to dismiss, the Court sided with the plaintiffs.

\section{Properly Defined Relevant Markets}

The Court looked at whether the plaintiffs properly defined a "relevant market." The plaintiffs identified two relevant markets: 1) live elite professional MMA bouts (relevant output market) and 2) live elite professional MMA fighter services (the relevant input market). Zuffa claimed that these definitions were made solely for the purpose of litigation and that they were vague and subjective. ${ }^{115}$ For instance, it argued the term "elite" is subjective and vague. The Court held that the validity of the "relevant market" is typically a factual element and not a legal element. As the Court notes, the market may survive an initial scrutiny under the motion to dismiss but may not under a motion for summary judgment or at trial. As such, it found that the plaintiffs' relevant market is sufficient for "Section 2" antitrust purposes.

\section{Specificity of Anticompetitive Conduct}

Zuffa argued that exclusive dealing arrangements are common, procompetitive, and a part of sports and entertainment. The plaintiffs failed to allege specific facts showing that the exclusive arrangements foreclosed competition in either the input or output market and the UFC has no duty to deal with competitors. The Court sided with the plaintiffs in agreeing with its allegations that exclusive dealing arrangements are a part of the anticompetitive scheme. It also dismissed the argument that the plaintiffs' claims are a "monopoly broth"- the term given to the use of various allegations to satisfy an antitrust scheme.

\section{Ancillary Rights and Reduced Competition}

The Court looked at the rights issue related to fighters signing off on their likenesses for purposes of Zuffa using them for things such as video games. Here, the Court utilized the same analysis as it did with the exclusive dealing contracts in finding that the plaintiffs pled sufficient facts to show an anti-competitive scheme.

The Court denying Zuffa's motion to dismiss should not be taken as a commentary on the strengths or weaknesses of the plaintiffs' complaint as a whole. It is only a ruling on whether or not the complaint was sufficient to pass standards required by the rules under 12(b)(6) of the Federal Rules of Civil Procedure. It was Zuffa's burden to carry in order to prove that the complaint lacked sufficient facts to move forward. Weighing the evidence in light of the non-moving party, the Court determined that the plaintiffs had pled a sufficient amount for the case to move forward.

\section{Analyzing the Three Combat Lawsuits}

Boxing's latest legal turmoil between Golden Boy, Top Rank, and Premier Boxing Champions underscore the legal hurdles of filing an antitrust lawsuit

${ }^{115}$ Judge Richard Boulware's Order, p. 11, supra at n. 114. 
in combat sports. The ongoing litigation between former UFC fighters and the organization will be an interesting lawsuit to follow. Based on what has transpired in the Golden Boy and Top Rank cases, one may anticipate the UFC filing for a motion for summary judgment to dismiss all claims. These three cases reflect the turbulent market of combat sports in which a limited number of organizations have a dominant share of industry while allegedly suppressing other competitors and providing lesser conditions for its contracted fighters. It also reflects an issue as to the definition of markets in this specific niche sport.

\section{Keys to Top Rank/Golden Boy v. Haymon Litigation}

Although not a direct result, former Golden Boy executive Richard Schaefer's departure from the company in 2014 likely set the table for the promotion's lawsuit with Al Haymon. Schaefer, a close friend of Oscar De La Hoya, helped found the promotion in 2002 and was its chief executive officer. He resigned in 2014 after a falling out with De La Hoya. Schaeffer had a working relationship with Haymon while De La Hoya did not. Haymon's fighters were featured on Golden Boy cards but were under no promotional contract with Golden Boy. ${ }^{116}$ This was rumored to be one of the sources of the division between the two. The rift caused a turbulent ending to their employment relationship as Schaefer and Golden Boy settled a dispute that went to arbitration in which the promotion sought $\$ 50$ million from Schaefer for breach of fiduciary duty. ${ }^{117}$ But the settlement agreement entered into by the parties limited the claim for which Golden Boy could claim its antitrust case. ${ }^{118}$ The settlement agreement, while never made public in full, surrendered Golden Boy's promotional rights to a number of Haymon boxers. ${ }^{119}$ Perhaps this limitation was key to Haymon's victory as Golden Boy's claims to those happening after January 1, 2015. Golden Boy "artfully pled" the lawsuit tailoring it to actions occurring after this date. ${ }^{120}$ It is significant as certain events occurred that fell in favor of Haymon. For instance, several inter-promotional fights occurred during this time including the big Floyd Mayweather-Manny Pacquiao fight, which happened in May 2015, and the Amir Khan-Canelo Alvarez fight, which took

\footnotetext{
${ }^{116}$ Dan Rafael, Richard Schaefer Leaves Golden Boy, ESPN.com, June 2, 2014, http://www.espn. com/boxing/story/_id/11022980/golden-boy-promotions-co-founder-richard-schaefer-steps-chief

${ }^{117}$ Kevin Iole, Golden Boy, Richard Schaefer Settle; GBP Parts Way with Most Al Haymon Fighters, Yahoo! Sports, January 9, 2015, http://sports.yahoo.com/blogs/boxing/golden-boy--richardschaefer-settle--gbp-parts-waywith-most-al-haymon-fighters-020545902.html

118 Settlement and Release Agreement affixed as Exhibit A to Decl. of Alan Haymon attached to Notice of Mot. and Mot. To Stay Action Pending Arbitrator's Decision on Arbitrability and Release of Claims; Mem. of Points and Authorities in Support Thereof; Decls of Alan Haymon and Jeremiah Reynolds in Support Thereof, supra at n. 48.

${ }^{119}$ Iole, supra at n. 117.

${ }^{120}$ Opening Brief Regarding Arbitrability and Release of Claims; Mem. of Points and Authorities in Support Thereof; Decls. of Alan Haymon and Jeremiah Reynolds in Support Thereof, JAMS Reference No. 1100080841, Assigned to the Honorable Daniel Weinstein (Ret.), July 23, 2015.
} 
place in May 2016. In fact, Haymon's attorneys argued that Golden Boy wanted "its cake and eat it too," painting an unsavory picture of Golden Boy. ${ }^{121}$

Another issue in the Golden Boy and Top Rank litigation was the lack of involvement by current boxers. Although Bernard Hopkins was considered an active fighter at the time of the filing of the lawsuit in the Golden Boy matter, there were no boxers that came forward on the side of the plaintiffs to speak about the issues they had with Haymon. ${ }^{122}$ While there may have been fighters that were willing to speak privately, the Court did not indicate any evidence from a fighter that would have persuaded it in any of its rulings.

Finally, although a subtle issue outlined by the Court, it noted the lack of attempt to negotiate with a Haymon fighter or negotiate with a network to have Golden Boy or Top Rank fights on revealed a lack of evidence from the plaintiffs. It may have not prevailed, but evidence reflecting it made an affirmative effort that may have defeated a dispositive motion.

\section{The UFC Antitrust Lawsuit}

Although it's far from over at the time of this writing, the antitrust lawsuit between former UFC fighters and the company have parallels with the boxing lawsuits. The sides argue over the relevant markets in which the purported anticompetitive scheme is taking place. The business methods of the UFC are called into question. The UFC argues that its exclusivity arrangements are procompetitive and legal. After surviving Zuffa's motion to dismiss, the parties enter the discovery phase in which a voluminous number of documents will be shipped back and forth from requests for production. Additionally, depositions will be taken in hopes of narrowing or expanding the breadth of the case. ${ }^{123}$

What is different is that based on the Court opinions in the Top Rank and Golden Boy case, Judge John Walter, who presided over both, determined that the two promotions were only speculating over market conditions and predatory practices of Haymon and PBC. There was not sufficient evidence that would conclude that PBC would not promote with either of the companies. More likely, it would be that PBC would be a difficult partner and/or seek a more advantageous deal if a partnership were brokered. Also, the Court held that investing and losing

\footnotetext{
${ }^{121} I d$.

${ }^{122}$ In its second amended complaint, Top Rank provided names of boxers including Deontay Wilder, Keith Thurman, Marcos Maidana, Adrien Broner, Lamont Peterson, Abner Mares, and Errol Spence that allegedly rebuffed other promotions due to the fact that Haymon "managed" them. Top Rank Boxing's Second Am. Compl. for Violations of Sherman Act and Calif. Unfair Competition Law, 2:15-cv-04961-JFW-MRW, see p.27, 28, October 30, 2015, ECF No. 86. See also Jason Cruz, Top Rank Files Second Amended Complaint Against Haymon, MMAPayout.com, October $31,2015$.

${ }^{123}$ Zuffa has filed a motion for partial summary judgment to dismiss the claims of plaintiff Nathan Quarry. See Zuffa LLC's Motion for Partial Summary Judgment As To Plaintiff Nathan Quarry on Statute of Limitations Grounds and Supporting Memorandum of Law, Le, et al. v. Zuffa, LLC, 2:15-cv-01045-RFB-(PAL), February 1, 2017, ECF No. 347. The motion is based on a production of documents as well as his deposition testimony. Zuffa claims that Quarry's claims are outside the statute of limitations.
} 
money in an endeavor is not a sign of a predatory practice. The "loss leader" allegation fell flat. So, the alleged "venue blocking" and "time buys" would not be considered evidence of a violation of antitrust laws.

Although the Ali Act was not a part of the UFC lawsuit, it is still an issue between fighters and the fight promotion. A proposed law to expand the Ali Act is still working its way through Congress with opposition from the UFC. In August 2017, UFC fighter Conor McGregor participated in a boxing match against Floyd Mayweather, Jr. in Las Vegas, Nevada. ${ }^{124}$ Zuffa applied to be co-promoter of the event in order to pay McGregor. ${ }^{125}$ While the need to be a promoter for the fight was necessary according to the Nevada rules, to pay McGregor, it brought up the notion that the UFC was acting as promoter and manager for McGregor.

Finally, it is clear that despite the fact that the perception of oppression that is painted by the fighters may be real, the use of antitrust laws must reveal a chain effect that harms consumers. If there is no link to show that the treatment of fighters harms consumers as a result, the likelihood of success is questionable. ${ }^{126}$

\section{The Future of Antitrust Litigation in Combat Sports}

There has been debate as to whether antitrust laws should regulate commercial sports leagues. ${ }^{127}$ Despite the effort to regulate sports, some legal commentators have found that the Sherman Act is "poorly suited" to regulate sports leagues due to their unique characteristics and "peculiar economics." 128 Some have suggested that the federal government intercede in regulating sports league due to the unique nature of the dominant league's "natural monopoly." Professor Nathaniel Grow suggests a federal sports commission should be established to oversee the leagues. The overarching theme of governmental oversight rather than application of antitrust laws is the concern for the consumer rather than constituent groups. ${ }^{129}$

\footnotetext{
${ }^{124}$ Tom Lutz, Floyd Mayweather-Conor McGregor Fight Agreed for 26 August, The Guardian, June 14, 2017, https://www.theguardian.com/sport/2017/jun/14/floyd-mayweather-conor-mcgregor-fight-date-approval

${ }^{125}$ Marc Raimondi, Nevada Commission Head Explains Why UFC Must be Mayweather vs. McGregor Co- Promoter, MMAFighting.com, August 22, 2017, https://www.mmafighting. com/2017/8/22/16182554/nevadacommission-head-explains-why-ufc-must-be-mayweather-vs-mcgregor-co-promoter

${ }^{126}$ Paul Gift, Former FTC Commissioner: UFC Investigations, Antitrust Lawsuit 'Ultimately About Consumers,' BloodyElbow.com, April 12, 2016, http://www.bloodyelbow. com/2016/4/12/11404276/former-commissionerjoshua-wright-ftc-investigation-antitrust-lawsuit-ufc-news

${ }^{127}$ Marc Edelman, In Defense of Sports Antitrust Law: A Response to Law Review Articles Calling for the Administrative Regulation of Commercial Sports, 72 WASH. \& LEE L. Rev. Online 210 (2015).

${ }^{128}$ Nathaniel Grow, Regulating Sports Leagues, 72 WaSH \& Lee L. Rev. 573 (2015).

${ }^{129}$ See Grow, supra; Edelman, supra at 215; see also Matthew Mitten \& Stephen Ross, Look to Regulatory, Not Antitrust, Solution for College Sports, SportsBusiness Journal, July 14, 2014, p. 23.
} 
Professors Matt Mitten and Stephen Ross argue that a regulatory commission with standards of transparency facilitate regulation with the NCAA. ${ }^{130}$ As noted in the conclusion of the opinion dismissing Golden Boy's claims against Haymon, antitrust laws are meant to protect consumers, not competitors. ${ }^{131}$

On the other hand, an opposing view from Professor Marc Edelman notes it is an imperfect science but antitrust laws are still the best way to regulate commercial sports leagues. ${ }^{132}$ Edelman also notes that the application of antitrust law to commercial sports has remained relatively free from political influence. ${ }^{133}$ Clearly, logistical and ethical issues factor into whether governmental handling of these issues take place. Special interest groups, lobbyists, and politicians are just three of the major concerns when establishing a governmental administration to oversee leagues. With the general wealth of a sports leagues, it's hard not to fathom that they would flex their political muscle in making sure that the interests of the league are well-represented. In combat sports, we have seen the UFC actively lobby for its causes in Washington. Recently, it has dedicated money to oppose the expansion of the Ali Act to include mixed martial arts. ${ }^{134}$

Edelman notes that labor-side antitrust litigation involving professional sports leagues has decreased due to the fact that players in the NFL, NBA, MLB, and NHL have unionized. ${ }^{135}$ He provides several examples in which antitrust law has facilitated favorable results for the consumers in the context of lawsuits involving the NCAA. But, none of the examples relate to combat sports. He also notes that Antitrust's Rule of Reason analysis was specifically designed to address more unusual marketplaces, such as commercial sports. ${ }^{136}$ Undoubtedly, combat sports is a unique marketplace. It would be difficult to surmise a scenario where the Golden Boy, Top Rank, or UFC lawsuits would prevail on a "per se" analysis under Section 1 of the Sherman Act. While the plaintiffs in the UFC lawsuit have survived at the initial 12(b)(6) dismissal stage, the definition of market is still subject to factual attack by the UFC. ${ }^{137}$

\footnotetext{
${ }^{130}$ Mitten \& Ross, supra.

${ }^{131}$ Golden Boy Dismissal, supra at n. 44.

${ }^{132}$ Edelman, at p. 217, supra n. 127.

${ }^{133}$ Edelman, at p. 212, supra n. 127.

${ }^{134}$ Tim Bissell, UFC Doubles Lobbying Efforts on the Ali Act Expansion Act, BloodyElbow.com, November 21, 2016, http://www.bloodyelbow.com/2016/11/21/13642344/ufc-doubles-lobbying-efforts-on-the-muhammad-ali-actzuffa-politics-lobby-legal-law-piracy-mma-news

${ }^{135}$ Edelman, supra at 218 (citing Marc Edelman \& Geoffrey Christopher Rapp, Careers in Sports Law, 51-52 (2015).

${ }^{136}$ See L.A. Mem'l Coliseum Inc. v. Nat'l Football League, 726 F.2d 1381, 1401 (9th Cir. 1983)

(favoring a rule of reason test rather than a per se test for illegality in professional sports).

${ }^{137}$ Notably, the Court in the Golden Boy opinion dismissing the case on summary judgment, held that the market definition set forth by its expert exposed fundamental flaws. Golden Boy Dismissal, supra n. 41 at p. 13 .
} 


\section{Evaluating Recent Antitrust Cases}

Combat sports is unique. Unlike team sports, boxing is an individual sport that is driven by fighters and their promoters. Managers assist fighters in a variety of ways and should help facilitate a working relationship with promoters. While leagues are a collaboration of teams with a central goal to increase revenue, leagues - or sanctioning bodies - in boxing are not a driving force. Rather, Top Rank, Golden Boy, PBC, and other promotions are the major drivers in the sport while the boxers are the engine. There are two recent instances in which plaintiffs have filed lawsuits against sport organizations based on antitrust violations. ${ }^{138}$ Those lawsuits have failed to sustain an antitrust claim and were dismissed in the initial pleading stage. They are interesting in comparing and contrasting with the combat sports antitrust lawsuits.

The thrust of the William Michael Hicks, et al. v. PGA Tour, Inc. ("Hicks lawsuit") and the Gold Medal, LLC D/B/A Run Gum v. USA Track \& Field and United States Olympic Committee ${ }^{139}$ ("Run Gum lawsuit") dismissals were on the basis of the lack of identifying a market and a pre-existing antitrust exemption. Both cases are instructive regarding the ongoing hurdles for plaintiffs to identify relevant markets for which to claim a violation of the antitrust laws.

In the Hicks lawsuit, the Court dismissed with prejudice the antitrust lawsuit brought by a number of golf caddies on the Professional Golfers Association ("PGA") Tour. ${ }^{140}$ The caddies cited violations of Sherman Act sections 1 and 2 against the PGA Tour claiming that they compelled caddies to wear logos and other insignia of corporate sponsors on the bibs that they wear during a round of golf. Essentially, they are made "human billboards" for sponsor advertisements that pay the PGA Tour while not receiving direct compensation. ${ }^{141}$ Notably, individual golfers, and not the PGA Tour, employ the caddies but must comply with the tour rules to participate in its tournaments. Under Sherman Act $\$ 1$, the caddies claimed the PGA Tour conspired with local tournament organizations in cooperating to limit competition. ${ }^{142}$ Thus, local tournaments holding the PGA Tour events engaged in enforcing rules that required caddies to wear bibs adorning tour sponsors. Under Sherman Act $\$ 2$, caddies claimed that the PGA Tour had monopoly power in the "endorsement market" and used this influence on the "live action advertising market."143

The Court did not address the substantive legalities found in the caddies' antitrust claims because it determined that it did not properly define a market,

\footnotetext{
${ }^{138}$ Hicks, et al. v. PGA Tour, Inc., 165 F. Supp. 3d 898 (N.D. Cal. 2016); Gold Medal LLC d/b/a Run Gum v. USA Track \& Field and United States Olympic Committee 187 F. Supp. 3d 1219 (D. Or., 2016).

${ }^{139}$ Gold Medal LLC, supra.

${ }^{140}$ Hicks, supra at n. 138.

${ }^{141} I d$.

${ }^{142} I d$.

${ }^{143}$ Hicks, p. 18, supra at 138.
} 
which is a prerequisite for any antitrust claim. ${ }^{144}$ It held that the markets asserted by the caddies were not plausible and dismissed the case with prejudice as it determined that they could not overcome this initial hurdle. To implicate the antitrust laws, the Court opined that the caddies must allege facts from which one could plausibly conclude that these different methods of advertising to golf fans are not reasonably interchangeable, such that even if the price of one advertising method went up in a meaningful way, companies would not switch to another method of advertising. ${ }^{145}$

In its lawsuit, the caddies alleged two relevant product markets in which the PGA Tour committed antitrust violations. They labeled it the "endorsement market" and the "live action advertising market."146 They claim that advertisers of certain products seek the attention of pro golf fans. Based on the market demographics, the advertisers are companies that have products in the luxury goods and services. The endorsement market is "the national market for the endorsement of products and services by participants in professional golf tournaments." 147 They described the live action advertising market as the market for "in play or in-action commercial advertising at professional golf events between commercial breaks." This market is limited to things people see when they're watching the golf "action" on TV. They assert that these markets are distinct and not interchangeable. However, the court disagreed. "To implicate the antitrust laws, the caddies must allege facts from which one could plausibly conclude that these different methods of advertising to golf fans are not reasonably interchangeable, such that even if one advertising method went up in a meaningful way, companies would not switch to another method of advertising." 148 The Court concluded that the caddies failed to provide these facts.

The conduct of a seller only implicates the antitrust laws if it allows the seller to charge artificially high prices in a scenario in which consumers have no reasonable opportunity to turn to another product. ${ }^{149}$ It is necessary to examine the entire product market in order to decipher the purported harm. ${ }^{150}$ If consumers are not precluded from responding to the defendant's conduct simply by turning to reasonable alternatives in the market, the conduct of the defendant was not meant to be covered by the antitrust laws. ${ }^{151}$ In the caddie case, the Court held that the product markets proposed were not natural and artificial to meet the needs of litigation. Thus, the Court dismissed the claim with prejudice.

\footnotetext{
${ }^{144}$ Id. at p. $10-11$.

${ }^{145} \mathrm{Id}$.

${ }^{146}$ Plaintiffs' Original Class Action Compl. for Damages, Hicks, et al. v. PGA Tour, Inc. 15-cv00489-VC , (9th Cir. February 3, 2015, ECF No. 1.

${ }^{147}$ Id. at p. 14-15, supra at n. 138.

${ }^{148}$ Op. and Order, at p. 13, Hicks, et al. v. PGA Tour, supra at n. 138.

${ }^{149}$ Id. at p. 11.

${ }^{150} I d$.

${ }^{151} I d$.
} 
In the Run Gum lawsuit, Gold Medal, LLC dba Run Gum brought a lawsuit against the United States Olympic Committee ("USOC") and United States Track \& Field ("USTF") citing an illegal restraint of trade under Section 1 of the Sherman Antitrust Act. ${ }^{152}$ Run Gum asserted that USOC and USTF's rule restricting advertising and logos on athlete apparel while competing in the 2016 Olympic Trials restrained trade. The rules that allowed certain logos to be shown while others could not be was cited as a horizontal and vertical agreement between USOC, USTF, and others to restrain trade illegally. Since this was a purported conscious commitment to a conspiracy between two or more entities the allegation was pursuant to Section 1 of the Sherman Act. However, the Run Gun lawsuit falls flat on its antitrust allegations as the Court stated that that it had not properly defined the market.

Similar to the Hicks lawsuit, the court highlighted that the USOC and USTF made "strong arguments" challenging the alleged market and inferred it was "unnatural." 153 The USOC noted the caddies had alleged an "impossibly narrow, single-event alleged 'relevant market' in the complaint - a particular type of advertising (a third-party logo on an athlete's attire) at one particular location (the field of competition) during one particular event (the 2016 Track \& Field Olympic Trial) - is at odds both with common sense and with Run Gum's own deceptions of the other advertising opportunities that it enjoys." 154 Here, the Court acknowledged other relevant markets that could be as interchangeable.

Notwithstanding the Court's scrutiny of the purported markets, it denies Run Gum's allegations for a "per se" analysis as the Court notes the complaint "contains plenty of boilerplate antitrust language, it lacks any specific factual allegations as to any potential horizontal co-conspirator."'155 There were no facts supporting a theory that apparel and equipment manufacturers conspired with each other or with the USOC and USTF to restrain trade.

In comparison with the Golden Boy, Top Rank, and UFC cases, the antitrust plaintiffs did not have a unified association and/or union acting on its behalf that collectively bargain. None of the plaintiffs were considered employees of the defendants it was suing. In the case of the Run Gum litigation, the individual athlete that spoke out against the USOC and USTF rules owned a portion of Run Gum. ${ }^{156}$ The athlete, who participated in USTF events, was critical that he was unable to earn money from sponsors during the events. The court in each lawsuit had issues with the markets they defined. In the case of Hicks and Run Gum, the Court did not believe they had properly defined a market, citing each as narrow, and believed that they were manufactured for purposes of litigation. A fatal flaw in each was the inability to show the lack of interchangeability in a market. In

\footnotetext{
${ }^{152}$ Compl., p. 23-24, Hicks, et al. v. PGA Tour, Inc., 6:16-cv-92, January 20, 2016, supra at n. 138.

${ }^{153}$ Id., Opinion and Order, p. 9. (citing Hicks lawsuit).

${ }^{154}$ Id., p. $9-10$.

${ }^{155}$ Id., p. 12.

${ }^{156}$ SI Wire, Olympian Nick Symmond's Company Files Lawsuit vs USOC and USATF, Sports Illustrated, January 20, 2016, https://www.si.com/more-sports/2016/01/20/nick-symmonds-lawsuit-usoc-usatf-run-gum-athletesponsorship-us-olympic-trials
} 
the Golden Boy case, the judge disagreed with the market definition based on the expert's opinion of the market. Noteworthy, it criticized Golden Boy's expert for failing to evaluate the interchangeability of the product market. Similarly, Haymon attorneys attacked Top Rank's definition of market in its lawsuit. While the Court has not made a definitive ruling on the market in the UFC case, the defendants take issue with the market definition set forth by the plaintiffs. Thus, the market definition in these lawsuits are tenuous due in part to the unique nature of the sport and the marketplace each serves.

\section{A Look at International Boxing v. United States}

The market definition for combat sports brings into scrutiny the seminal case of International Boxing Club of New York v. United States ("International Boxing"), which laid the groundwork for the two boxing cases and as possible guidance for the UFC lawsuit. In that case, the District Court held that championship boxing events are uniquely attractive to fans and constitute a market separate from that for non-championship events. ${ }^{157}$ The U.S. Department of Justice investigated the International Boxing Club of New York for potential antitrust violations. Similar to the ruling in Toolson v. New York Yankees, International Boxing claimed that it should have received an antitrust exemption similar to that of baseball as interstate travel was incidental to the staging of fights. ${ }^{158}$ However, the U.S. Supreme Court opined that baseball's antitrust exemption did not apply to the boxing business. After a remand and trial, the U.S. Government prevailed and International Boxing Club of New York was dissolved. ${ }^{159}$

In International Boxing, the U.S. Supreme Court upheld the defined market relying on the $d u$ Pont court's definition of market: "The tests are constant. That market is composed of products that have reasonable interchangeability for the purposes for which they are produced-price, use, and qualities considered." 160 The district court utilized the market definition in finding a "separate, identifiable market" for championship boxing contests. The court highlighted its conclusion by comparing the revenues of championship bouts versus non-championship bouts, television rights, ratings, movie rights, and ticket prices. It was clear that championship bouts drew more in revenue, viewership, and ticket demand, resulting in higher prices than non-championship bouts. Based on this information, the district court concluded that championship boxing was the "cream" of the boxing business and was sufficiently a separate part of the trade or commerce to constitute the relevant market for Sherman Act purposes. ${ }^{161}$

\footnotetext{
${ }^{157}$ International Boxing Club of New York, Inc. v. United States, 358 U.S. 242, 249-252 (1959).

${ }^{158}$ See Toolson v. New York Yankees, 346 U.S. 356 (1593) (the United States Supreme Court upheld the antitrust exemption granted to Major League Baseball).

${ }^{159}$ International Boxing, at 249, supra at n.157.

${ }^{160}$ Id., see also United States v. E.I. du Pont de Nemours \& Co., 351 U.S. 377, 404 (1956).

${ }^{161} I d$.
} 
The key market definition distinction in the International Boxing decision rests upon the evidence showing the purported markets. In the order dismissing Top Rank's first amended complaint, the judge noted that while Top Rank's definitions of relevant markets survived the pleading stage, it did not show Haymon had market power or economic power in the defined relevant markets. ${ }^{162}$ Interestingly, the same judge presided over the Golden Boy case and did not believe that Golden Boy sufficiently defined the market in opposing Haymon's summary judgment motion.

Similarly, in its motion to dismiss, the UFC claimed that the plaintiffs had made up the market of "elite professional MMA fighters" as a "term not used in the industry and apparently created solely for the purpose of this litigation."163 Particularly, they question the connotation of "elite" and state that they do not allege why a professional MMA fighter is not a reasonable substitute for an elite professional MMA fighter. ${ }^{164}$ Their contention was that it narrowed the market for its own purpose and the plaintiffs' statement that "all or virtually all ... Elite Professional MMA fighters" are under contract to the UFC. ${ }^{165}$ In its order denying the UFC's motion to dismiss, it held that the plaintiffs' relevant market is sufficient for Section 2 purposes. ${ }^{166}$ As it concluded in Top Rank, the Court also stated that the validity of the "relevant market" is typically a factual element rather than a legal element under a Rule 12(b)(6) analysis. However, it may be overturned at summary judgment or trial.

The International Boxing decision occurred in a different era prior to the invention of MMA and the UFC. It also was a predecessor for promotions such as Golden Boy, Top Rank, and PBC. So, one might inquire whether the market analysis of International Boxing may still hold true in this era. The comparison of the revenues from "championship" level fights versus "non-title" fights were easy to evaluate in International Boxing. However, one might argue it would be harder to make an easy distinction in the present era where a championship belt may not be the distinguishing factor for these combat sports markets. In the UFC lawsuit, the plaintiffs make this argument when identifying the relevant markets in its lawsuit. In this era, the marketing and promotion of a fighter and event appear to be much more important than whether a fight is for a title.

\section{Conclusion}

The three antitrust lawsuits challenge the business structure of existing organizations. In the case of the boxing lawsuits, rival organizations sought to stop

${ }^{162}$ Order Granting in Part the Haymon Defendants' Mot. to Dismiss Pursuant to FRCP 12(b)(6), p. 7-9, Top Rank, Inc., v. Al Haymon, et al., supra at n. 86.

${ }^{163}$ Zuffa Mot. to Dismiss, p. 17, Le, supra at n. 96.

${ }^{164}$ Id. at p. 18.

${ }^{165} \mathrm{Id}$.

${ }^{166}$ Order entered on October 19, 2016, regarding Zuffa, LLC's Mot. to Dismiss, Lead Case No.

2:15-cv-01045-RFBPAL, Le v. Zuffa, LLC, ECF No. 314. 
an upstart with a seemingly endless amount of capital and an aggressive plan of expansion. PBC is seeping money at an alarming rate, which has caused concern for some investors. ${ }^{167}$ Yet, application of antitrust laws, at least in the Golden Boy lawsuit, was found not to violate Sherman Act 1 or 2 . One might argue that you may find a similar ending in the Top Rank case but for the settlement. ${ }^{168}$ The UFC lawsuit is ongoing with depositions and discovery in full throttle. Unless there is something game changing discovered during this time period, expect Zuffa to file a motion for summary judgment prior to trial. Similar to its motion to dismiss, it will focus on the inability to define a relevant market, and even if there is a defined market no facts support the plaintiffs' claim of an illegal restraint of trade or monopoly over the market. The overarching theme for Zuffa is that the antitrust laws are for the benefit of protecting the consumers, not competitors.

These lawsuits may seem unfair for those wishing better market conditions for MMA fighters or competition in the boxing industry. There have been proposals for government oversight of professional leagues to alleviate the set monopolies. Yet, such governmental inclusion might invite politics and lobbyists within the realm of regulation. The definition of markets is another hurdle these lawsuits have faced, and despite the guidance of International Boxing, more recent lawsuits reflect the difficulty of determining a proper market to show a violation of the antitrust laws.

Another alternative to litigation under antitrust laws could be the expansion of the Muhammad Ali Act to protect fighters. ${ }^{169}$ In May 2016, a bill was introduced to expand the Ali Act to include mixed martial artists. ${ }^{170}$ The proposed legislation would provide guidelines for minimum contractual provisions in MMA bout agreements and other combat sports, guidelines for objective and consistent written criteria for the ratings of MMA and other combat sports, as

\footnotetext{
${ }^{167}$ Larry Pugmire, Al Haymon Is Spending to Put Boxing on TV, But Do the Numbers Add Up? Los Angeles Times, February 2, 2016, http://www.latimes.com/sports/la-sp-al-haymon-boxing20160203-story.html

${ }^{168}$ As noted in the Top Rank lawsuit, the Court dismissed Top Rank's complaint but allowed for it to amend. The parties settled their case soon thereafter. Although the settlement was not made public, a portion of it appears to be PBC relinquishing exclusive rights to certain networks. As a result, in early 2017, Golden Boy and ESPN announced a partnership beginning in March 2017. See Dan Rafael, 'Golden Boy Boxing on ESPN' Begins Partnership in March, ESPN.com, January 17, 2017, http://www.espn.com/boxing/story/_id/18508305/golden-boy-promotionsespn-enterpartnership-42-fight-cards-next-two-years. Top Rank has now brokered a deal with ESPN to air its fights on the network that started in July 2017. See Dan Rafael, Top Rank Signs Exclusive Four-Year Deal with ESPN, August 26, 2017, ESPN.com, http://www.espn.com/boxing/story/_ / $\mathrm{id} / 20465923 /$ top-rank-espn-hammercomplicated-deal-bring-top-rank-fights-exclusively-espn-platforms-years-come

${ }^{169}$ H.R. 5365 Muhammad Ali Expansion Act (2015-2016), https://www.congress.gov/ bill/114th-congress/housebill/5365/text?format $=$ txt

${ }^{170}$ Brett Okamoto, Ali Act Amendment Could Expand Federal Law's Coverage to MMA, ESPN. com, May 19, 2016, http:/www.espn.com/mma/story/_id/15589773/bill-aims-expand-muhammad-ali-boxing-reform-act-mma
} 
well as address conflict of interest provisions. ${ }^{171}$ While the legislation would offer a deterrent, the application of the Ali Act in the boxing world has provided less than positive results. ${ }^{172}$

As efforts to create a union or association in MMA have met its own hurdles and logistical issues, organizations for fighters might be the key to setting a baseline for working conditions including salaries, ancillary rights, and other benefits. A reason why there is little labor-side antitrust litigation in the four major leagues is due to the creation of a union/player's association in each one. This might be difficult in the world of mixed martial arts since there are a variety of MMA organizations aside from the UFC. Also, the global reach of MMA might make a universal organization not feasible. Moreover, there are a variety of unions and associations competing to organize fighters. ${ }^{173}$ But, these efforts have been met with skepticism, citing issues with ulterior motives and lack of trust in some of its advisors. ${ }^{174}$ What can be learned from the three antitrust cases discussed is that antitrust laws protect consumers notwithstanding harm that may occur to companies or fighters in the industry. If fighters and companies intend to address disputes with leagues, it might be prudent to look to alternative means of resolution. For companies-like competing in the ring, cage, or octagon-you have to outdo your opponent no matter what the odds.

\footnotetext{
${ }^{171}$ See Muhammad Ali Expansion Act, supra. at n. 169.

${ }^{172}$ Jason Cruz, Is the Muhammad Ali Act Helping Protect Fighters? The White Bronco, May 2, 2016, http://thewhitebronco.com/2016/05/is-the-muhammad-ali-act-helping-protect-fighters/

173 Jason Cruz, MMA Fighters Announce Formation of New Union, The White Bronco, December 1, 2016, http://thewhitebronco.com/2016/12/mma-fighters-announce-formation-of-new-union/, see also Professional Fighters Association Announces Formation of Union Geared Toward UFC Athletes, December 1, 2016, MMA Junkie, http://mmajunkie.com/2016/08/professional-fighters-association-announces-formation-of-union-geared-toward-ufc-athletes

${ }^{174}$ Brett Okamoto, Dana White Takes Issue with Bjorn Rebney for MMAAA Advisory Role, ESPN.com, December 6, 2016, http://www.espn.com/mma/story/_id/18224345/dana-white-takesissue-bjorn-rebney-mmaaa-advisory-role
} 